\title{
Design of Nano Polymer Orthoses
}

\author{
Gilberto Pavani ${ }^{1}$, Ricardo Pavani ${ }^{2}$ and Régio Pierre da Silva ${ }^{3}$ \\ ${ }^{1}$ Instituto Federal do Rio Grande do Sul, Brazil \\ ${ }^{2}$ Central University Center, Brazil
}

${ }^{3}$ Federal University of Rio Grande do Sul, Brazil

Submission: February 10, 2017; Published: March 09, 2017

*Corresponding author: Gilberto Pavani, Instituto Federal do Rio Grande do Sul, Brazil, Tel: +55(51) 98619-1964;

Email: gilberto.pavani@farroupilha.ifrs.edu.br

\begin{abstract}
This work has the opinion of the authors about the conception, design and manufacturing processes of nano polymer orthoses as an interface between the organic and inorganic realities through the symbiogenic approach mediated by assistive technologies that aim to fulfill and amplify the functionalities of the human body. The development of orthoses requires serious study of the human singularities, needing an approach that integrates different areas of knowledge such as physiology, design and material engineering in order to satisfy the needs of people with reduced functional capabilities. The objective of this work is to broaden the discussion about independence and the safe practice of social activities that involve work, leisure and sports, using orthoses developed with nano polymer, aiming to offer more comfort to the user, for being lighter, more resistant and more durable than the existing products, as well as being recyclable, helping with the preservation of the environment.
\end{abstract}

Keywords: Orthoses; Nano Polymers; Design; Assistive Technology

\section{Introduction}

ISO 8549-1:1989 - Prosthetics and orthotics - Vocabulary Part 1: General terms for external limb prostheses and external orthoses, presents definitions of terms used to describe artificial limbs, the anatomy of those parts of the human body [1] However, the term orthosis is used to define any medical device applied to a body segment in case of physical or motor disability [2]. The loss of functionality often makes daily activities impossible, requiring assistive technology solutions in order to improve the quality of life of people with motor disabilities, especially for laboral activities. In this context, meeting the needs of people with special needs involves the integration of several technologies that aim to fulfill and amplify functional deficits through orthoses [3], whose technological advancement involves the use of new materials such as nano-polymers.

Assistive technology applies resources, methodologies and strategies in order to amplify the functionalities of people with temporary or permanent disabilities, allowing the performance of tasks needed for social integration, being the design indispensable for the insertion of new technologies such as nano-polymers. The development of an assistive product is a multidisciplinary process that involves several areas of knowledge such as physiology that indicates the means to amplify the autonomy if the user and engineering that presents technological solutions, resulting in a functional design. Thus, the symbiogenic approach is a theoretical base resource for the comprehension of the complexity coming from the organic and inorganic interactions between body and machine [4], in this case, the symbiosis between the person with reduced functionality and the orthosis.

In the beginning of the 20th century, designers sought a particular aesthetic for industrialized products [5], but when form no longer met functionality, the use of polymeric materials such as bakelite allowed industrial products that met the antropometric and ergonomical parameters to be made [6]. Technological advancements allowed the creation of nano composites that result of the combination between two or more materials with different properties, the disperse phase being presented in at least one of their dimensions in a nano metric scale, being used in small quantities, usually $5 \%$ of its weight [7]. 
Montmorillonite clay is the most used inorganic phase in the preparation of polymer nano composites due to its high aspect ratio, good shearing capabilities, high resistance to solvents and thermal stability adequate to the polymerization and extrusion processes [8].

Polymer nano composites have properties superior to those of conventional polymers and composites, as they have higher resistance to strain and module, because of their reduced dimensions and adequate shearing of the nano particles which increase their mechanical properties [9]. The processing conditions are fundamental, seeing as nano composites manufactured in corotating twin screw extruders have higher exfoliation and shearing than the ones processed in mono screw ones, generally used in the processing of polymers [10]. Despite the recent advances in the production of tridimensional nano polymer pieces in fast prototyping [11], there is a need for research and development in order to obtain the same mechanical resistance obtained by the extrusion process, for example.

\section{Conclusion}

The challenge of designing an orthosis, i.e., a non invasive orthopedic device, with the goal to prevent or correct deformities, as well as improving the functionality of moving parts of the body [12], requires knowledge of ergonomics, functional anatomy, pathology and of the chosen material for the manufacturing of the orthosis. Nowadays, assistive technology contributes to the development of new products considering the technical and scientific conjectures in meeting the needs of people with disabilities, aiming to increase their quality of life through a design that ensures comfort, efficiency and safety. However, new materials such as polymeric nano composites must be used for the production of orthoses, aiming to meet the needs of the user relating to mobility and comfort when doing social activities.

\section{References}

1. International Organization for Standardization.

2. John Hsu, John Michael, John Fisk (2008) Atlas of Orthoses and Assistive Devices $4^{\text {th }}$ (Edn), pp 672.

3. Rachel E Cowan, Benjamin J Fregly, Michael L Boninger, Leighton Chan, Mary M Rodgers, et al. (2012) Recent trends in assistive technology for mobility, Journal of Neuro Engineering and Rehabilitation 9: 20.

4. Lima G (2005) Nômades de Pedra: teoria da sociedade simbiogênica, Porto Alegre: Escritos, Brazil.

5. Moraes D (1999) Limits do Design, São Paulo: Studio Nobel Brazil.

6. Dreyfuss H (2012) Designing for People. New York, Allworth Press.

7. Koo JH (2000) Polymer Nano composites: Processing, Characterization and Applications, McGraw-Hill, USA.

8. McNally T, Murphy WR, Lew CY, Turner RJ, Brennan GP (2009) Polyamide-12 layered silicate nano composites by melt compounding. Polymer 44(9): 2761-2772.

9. Nath DC, Bandyopadhyay S, Yu A, Zeng Q Das T, et al. (2009) White C. J Mater Sci 44: 6078.

10. Jin YH, Park HJ, Im SS, Kwak SY, Kwak S (2002) Polyethylene/clay nanocomposite by in situ exfoliation of montmorillonite during Ziegler-Natta polymerization of ethylene. Macromol Rapid Commun 23(2): 135-40.

11. Minamimoto H, Irie H, Uematsu T, Tsuda T, Imanishi A, et al. (2015) Polymerization of room-temperature ionic liquid monomers by electron beam irradiation with the aim of fabricating threedimensional micropolymer/nanopolymer structures, Langmuir 31(14): 4281-4289.

12. Pratt DJ (1994) Some aspects of modern orthotics, Physiological Measurement 15(1): 1-27.

Your next submission with JuniperPublishers will reach you the below assets

- Quality Editorial service

- Swift Peer Review

- Reprints availability

- E-prints Service

- Manuscript Podcast for convenient understanding

- Global attainment for your research

- Manuscript accessibility in different formats (Pdf, E-pub, Full Text, Audio)

- Unceasing customer service

Track the below URL for one-step submission https://juniperpublishers.com/submit-manuscript.php 